\title{
Validity of Research Based Bioremediation Text Books
}

\author{
Suri Puspita ${ }^{1 *}$, Yuni Ahda ${ }^{1}$ \\ ${ }^{1}$ Biology Department, Math and Natural Science Faculty, Universitas Negeri Padang, Padang, Indonesia \\ *Corresponding author. Email: suripuspita92@gmail.com
}

\begin{abstract}
This textbook was designed to facilitate readers in obtaining information regarding bioremediation research. Bioremediation is one of the environment-friendly solutions that utilize microorganisms to overcome increasing pollution. The integration of the results of bioremediation research in textbooks is expected to help readers reduce or eliminate the presence of pollutants in the environment. The method of this research is Research and Development ( $\mathrm{R}$ and $\mathrm{D})$ by using the plomp model development procedure (Preliminary research phase, development or prototyping phase, and assessment phase). Instruments in this study are interview guidelines and questionnaires. The study shows that $82 \%$ of students need the latest issues of bioremediation and $77 \%$ of students need bioremediation textbooks based on the research. Students have difficulty understand information from international articles. The value of validation on the content aspect is $87,50 \%$, while in the language, graphics and construct aspects are 79,16\%,75\% and 84,09\% respectively. The categories of value above are valid, but validator gives some suggestions, like clarifying the basis of classifying material chapters and sub-chapters, adjusting the writing rules according to EBI, and layout of bioremediationtextbooks. Validation results are valid criteria so that it is feasible to be used as a learning resource in bioremediation material.

Keywords: Bioremediation, Development, Research, Textbooks, Validity.
\end{abstract}

\section{INTRODUCTION}

Indonesia's environmental conditions The more alarming seen from many environmental problems. One of the factors that arise from environmental problems is the increase in population. Other factors are also influenced by the number of industrial estates that cannot be separated from human activities (Soemarwoto, 2004: 259). The increasing population will certainly increase the number of industries and will produce waste such as household waste, palm oil liquid waste, paper processing, tofu and tempeh processing, and solid waste from the garbage disposal that does not comply with AMDAL requirements. This condition certainly has the potential to reduce environmental quality.

The importance of preserving the environment is realized through the socialization of increasing public awareness to be responsible and to protect the natural surroundings. Another effort is to utilize living organisms as pollutant degrading agents, known as bioremediation. Bioremediation is an option because it has more value than an environmentally friendly process (Astuti, 2016: 5).
Bioremediation is the process of using microorganisms aims to reduce environmental contaminants in a less toxic form (Heerden, 2018: 2).Bioremediation is the process of removing pollutants and chemical components that are toxic in the environment by using microorganisms such as bacteria, algae, multicellular and unicellular fungi (Astuti, 2016: 5). So, bioremediation can be used as a solution to polluted environmental problems.

Utilization of microorganisms aims to reduce, clean the soil area or body of polluted waters. This information is important to be obtained by the general public especially students are to know what should be done in dealing with waste, especially in the environment where he lives. Bioremediation research due to pollutants has been carried out by researchers all over the world but not everyone can access or be interested in reading the results of these studies. Related to this, it is necessary to provide precise information in the education process regarding what conditions and problems are currently or will be faced by Indonesia. An alternative that can be done is to integrate information on environmental problems in the learning process by expanding information through reading 
material, one of which is in the form of textbooks. Textbooks as learning tools are generally used to support teaching programs (Tarigan and Tarigan, 2009: 12).

The results of the researchers' interview with lecturers in Biotechnology, the State University of Padang and Bung Hatta University on December 26, 2019, revealed that the subject of bioremediation was in biotechnology courses at tertiary institutions and was only discussed in one meeting. Students still lack references even though they are given the flexibility to search, read, and obtain information related to lectures through the sophistication of science and technology at this time. The lecturer directs students to search for material through national or international journals. Because the development of biotechnology is fast so the solution is to read the article. However, in reality, the students will only read one or two journals and more in national journals. The low competency of students in understanding books or articles presented in English is relevant to the availability of bioremediation books which are still few presented in Indonesian. Textbooks that are commonly used also do not specifically contain the results of the latest research developments. Student understanding should be in line with current research developments. The need for data, facts and how to control pollution becomes very important so that students need textbooks that can make it easier to obtain bioremediation material.

The results of the questionnaire analysis filled out by students showed that $82 \%$ needed bioremediation textbooks, $77 \%$ agreed if the book was integrated with research results because $91 \%$ of students did not know the research that was developing at this time. In addition, 57\% of students agreed that the availability of bioremediation textbooks in Indonesian on the campus was still lacking. The need for information related to efforts to tackle environmental problems is important for learning communities to obtain learning resources that are easily understood and in accordance with research developments. This fact encourages researchers to develop textbooks that are easily understood and easily accessed by readers with the aim of supporting the lecture process and disseminating current information to the wider community. This information can be used as an example to be applied in life because students and the community can act as agents to degrade polluted environments.

\section{METHODS}

\subsection{Design of the Study}

This type of research is research and development ( $\mathrm{R}$ and D) with the aim of producing valid, practical and effective textbooks. The development of this research-based textbook uses the Plomp development model. Consists of three stages, namely: the initial investigation phase (preliminary research phase), the stage of developing or making a prototype (development or prototyping phase) and the assessment phase (assessment phase). This research was conducted for undergraduate students (S1) at Padang State University. Bioremediation material was delivered in 3 meetings with a weight of 2 credits in August to September 2019.

\subsection{Procedure}

Development or Prototyping Phase consists of Text Book Analysis, Analysis Lecturer Response, Analysis of Problems and the Need, for More details, see Figure 1.

Participant

This research was conducted in an odd semester in August-September academic year 2019/2020. The subjects of this study were the 2017 biology education students from class A with 42 students and class B with 37 students.

Instrument

Instruments in this study are interview guidelines and questionnairesn for research-based bioremediation textbooks.

\subsection{Data Analysis}

The data analysis begins by providing scoring foreach item. Scoring is based on a Likert scale with provisions such as Table 1.

Table 1. Categories and Scores items

\begin{tabular}{|l|l|}
\hline Score & Category \\
\hline 4 & Very agree \\
\hline 3 & Agree \\
\hline 2 & Disagree \\
\hline 1 & Very disagree \\
\hline
\end{tabular}

Source. Joseph 2007. 


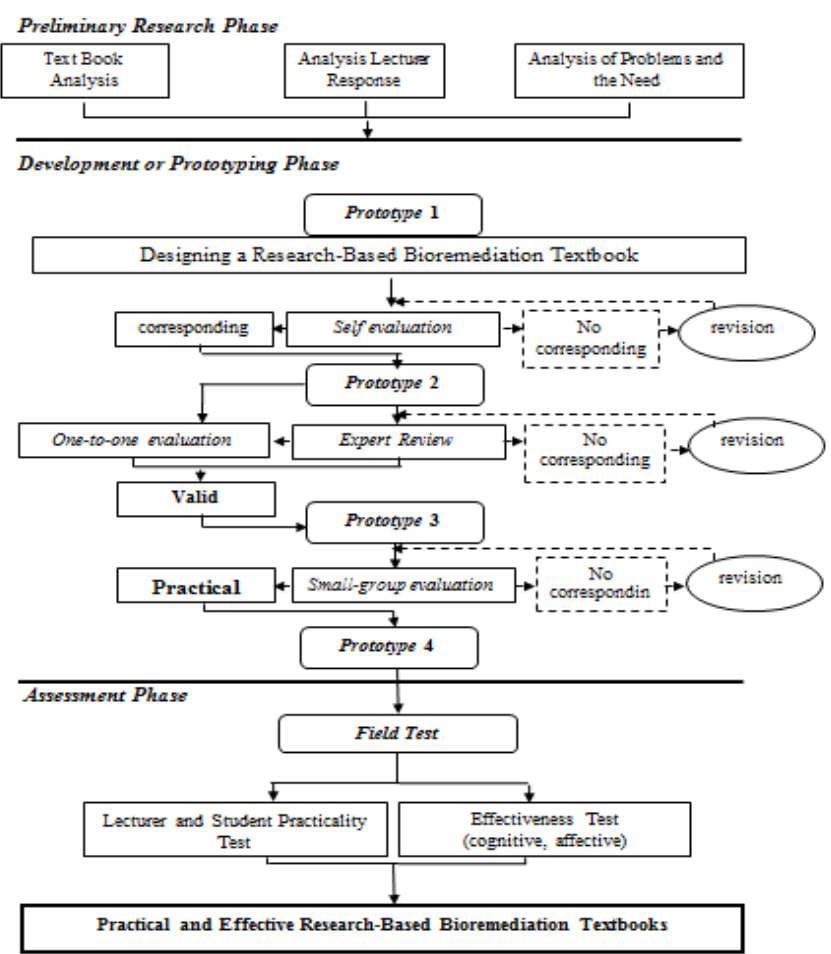

Figure 1. Research-Based Bioremediation Textbook Development Procedures.

Then, scoring results were tabulated and percentage by using this formula.

Percentage validity value $=$ $\frac{\text { Obtained score }}{\text { Maximun score }} x 100 \%$

Based on the validity score that was obtained, the assessment criteria of research-based bioremediation textbooks can use category in Table 2.

Table 2. Research-Based Textbook Validity Criteria

\begin{tabular}{|l|l|}
\hline Validity value (\%) & Category \\
\hline $0-20$ & Not Valid \\
\hline $21-40$ & Less Valid \\
\hline $41-60$ & Valid Enough \\
\hline $61-80$ & Valid \\
\hline $81-100$ & Very Valid \\
\hline
\end{tabular}

Source. Riduwan (2009: 88)

\section{RESULT AND DISCUSSION}

The textbook was validated by three validators who were in accordance with their fields of expertise. Validation covers the aspects of content, language, constructs, and graphics from a research-based bioremediation textbook. The conclusions of the validator suggestions for details, see Table 3.
Table3. Validator Suggestions for Textbook Improvements

\begin{tabular}{|c|c|}
\hline Validator & Suggestions \\
\hline $\begin{array}{l}\text { Dr. Dwi Hilda } \\
\text { Putri, M.Biomed. }\end{array}$ & $\begin{array}{l}\text { The textbook does not require } \\
\text { instruction, please removed } \\
\text { The basis for developing the } \\
\text { material to be discussed in the } \\
\text { chapters and sub-chapters described } \\
\text { must be clear. } \\
\text { the introduction to chapter I } \\
\text { Strengthen by data. } \\
\text { The introduction is presented with } \\
\text { the same space and type of writing } \\
\text { as the contents. }\end{array}$ \\
\hline $\begin{array}{l}\text { Dr. Darmansyah, } \\
\text { M.Pd. }\end{array}$ & $\begin{array}{l}\text { Reduce the density of material } \\
\text { content on pages that are full text } \\
\text { Focus on the placement of sources, } \\
\text { with the same and exact spacing } \\
\text { Select the source of the image by } \\
\text { paying attention to the contrast of } \\
\text { colors, sizes, etc. } \\
\text { Some pages must be more varied. } \\
\text { Note the position of the separate } \\
\text { sub-chapter titles with the contents } \\
\text { of the material } \\
\text { Page borders on the back cover } \\
\text { please removed. }\end{array}$ \\
\hline $\begin{array}{l}\text { Dr. Tressyalina, } \\
\text { M.Pd. }\end{array}$ & $\begin{array}{l}\text { Note the use of punctuation, } \\
\text { conjunctions, numbering, spaces, } \\
\text { and types of writing the introduction } \\
\text { with the description of the material. } \\
\text { Must be consistent in accordance } \\
\text { with Indonesian Spelling (EBI) in } \\
\text { writing. } \\
\text { Pay attention again to writing terms } \\
\text { that must be tilted. } \\
\text { Images consisting of a and b then } \\
\text { must be loaded in one box. } \\
\text { Give the introduction before } \\
\text { entering the description of the } \\
\text { material presented in tabular form. } \\
\text { The summary does not need to write } \\
\text { the source. } \\
\text { Writing the table of contents is just } \\
\text { aligned. }\end{array}$ \\
\hline
\end{tabular}

* The textbook has been revised in accordance with the three validators suggestions

In addition to the recommendations, the results of the validity of the research-based bioremediation textbook were also obtained through filling out a questionnaire by three validators, as follows: 
1. Content Aspects

\begin{tabular}{|l|l|l|l|l|l|l|}
\hline \multirow{2}{*}{$\begin{array}{l}\text { Indic } \\
\text { ators }\end{array}$} & \multicolumn{3}{|l|}{ Validator } & \multirow{2}{*}{ Average } & \multirow{2}{*}{$\%$} & Catagory \\
\cline { 2 - 6 } & 1 & 2 & 3 & & & \\
\hline 1 & 3 & 4 & 3 & 0.8333 & 83.33 & Very valid \\
\hline 2 & 4 & 4 & 4 & 1 & 100 & Very valid \\
\hline 3 & 4 & 4 & 3 & 0.9167 & 91.67 & Very valid \\
\hline 4 & 3 & 4 & 4 & 0.9167 & 91.67 & Very valid \\
\hline 5 & 4 & 4 & 3 & 0.9167 & 91.67 & Very valid \\
\hline 6 & 4 & 4 & 3 & 0.9167 & 91.67 & Very valid \\
\hline 7 & 3 & 4 & 4 & 0.9167 & 91.67 & Very valid \\
\hline 8 & 3 & 4 & 4 & 0.9167 & 91.67 & Very valid \\
\hline 9 & 4 & 4 & 3 & 0.9167 & 91.67 & Very valid \\
\hline 10 & 3 & 4 & 4 & 0.9167 & 91.67 & Very valid \\
\hline 11 & 3 & 4 & 4 & 0.9167 & 91.67 & Very valid \\
\hline 12 & 4 & 4 & 3 & 0.9167 & 91.67 & Very valid \\
\hline 13 & 4 & 4 & 3 & 0.9167 & 91.67 & Very valid \\
\hline 14 & 3 & 4 & 4 & 0.9167 & 91.67 & Very valid \\
\hline $\begin{array}{l}\text { Aver } \\
\text { age }\end{array}$ & 0, & 1 & 0,8 & & & \multirow{2}{*}{87} \\
\hline$\%$ & 87 & 10 & 87 & & & Very valid \\
\hline & & 0 & & & & \\
\hline
\end{tabular}

2. Language Aspects

\begin{tabular}{|c|c|c|c|c|c|c|}
\hline \multirow{2}{*}{$\begin{array}{l}\text { Indicat } \\
\text { ors }\end{array}$} & \multicolumn{3}{|c|}{ Validator } & \multirow[t]{2}{*}{ Average } & \multirow[t]{2}{*}{$\%$} & \multirow{2}{*}{$\begin{array}{l}\text { Catagor } \\
\mathrm{y}\end{array}$} \\
\hline & 1 & 2 & 3 & & & \\
\hline 1 & 4 & 4 & 3 & 0.9167 & 91.67 & $\begin{array}{l}\text { Very } \\
\text { valid }\end{array}$ \\
\hline 2 & 4 & 4 & 3 & 0.9167 & 91.67 & $\begin{array}{l}\text { Very } \\
\text { valid }\end{array}$ \\
\hline 3 & 3 & 4 & 4 & 0.9167 & 91.67 & $\begin{array}{l}\text { Very } \\
\text { valid }\end{array}$ \\
\hline 4 & 4 & 4 & 3 & 0.9167 & 91.67 & $\begin{array}{l}\text { Very } \\
\text { valid }\end{array}$ \\
\hline 5 & 4 & 4 & 3 & 0.9167 & 91.67 & $\begin{array}{l}\text { Very } \\
\text { valid }\end{array}$ \\
\hline 6 & 4 & 4 & 3 & 0.9167 & 91.67 & $\begin{array}{l}\text { Very } \\
\text { valid }\end{array}$ \\
\hline $\begin{array}{l}\text { Avera } \\
\text { ge }\end{array}$ & $\begin{array}{l}0.95 \\
8\end{array}$ & 1 & $\begin{array}{l}0.7 \\
91\end{array}$ & \multirow{2}{*}{\multicolumn{2}{|c|}{92}} & \multirow[t]{2}{*}{$\begin{array}{l}\text { Very } \\
\text { valid }\end{array}$} \\
\hline$\%$ & 96 & 100 & 79 & & & \\
\hline
\end{tabular}

3. Constructs Aspects

\begin{tabular}{|c|c|c|c|c|c|c|}
\hline \multirow{2}{*}{$\begin{array}{l}\text { Indicat } \\
\text { ors }\end{array}$} & \multicolumn{3}{|c|}{ Validator } & \multirow[t]{2}{*}{ Average } & \multirow[t]{2}{*}{$\%$} & \multirow[t]{2}{*}{ Catagory } \\
\hline & 1 & 2 & 3 & & & \\
\hline 1 & 3 & 3 & 3 & 0.75 & 75 & $\begin{array}{l}\text { Very } \\
\text { valid }\end{array}$ \\
\hline 2 & 3 & 3 & 3 & 0.75 & 75 & $\begin{array}{l}\text { Very } \\
\text { valid }\end{array}$ \\
\hline 3 & 3 & 3 & 3 & 0.75 & 75 & $\begin{array}{l}\text { Very } \\
\text { valid }\end{array}$ \\
\hline 4 & 4 & 4 & 4 & 1 & 100 & $\begin{array}{l}\text { Very } \\
\text { valid }\end{array}$ \\
\hline 5 & 3 & 4 & 4 & 0.92 & 92 & $\begin{array}{l}\text { Very } \\
\text { valid }\end{array}$ \\
\hline 6 & 4 & 4 & 4 & 1 & 100 & $\begin{array}{l}\text { Very } \\
\text { valid }\end{array}$ \\
\hline 7 & 3 & 4 & 4 & 0.92 & 92 & $\begin{array}{l}\text { Very } \\
\text { valid }\end{array}$ \\
\hline 8 & 4 & 3 & 3 & 0.83 & 83 & $\begin{array}{l}\text { Very } \\
\text { valid }\end{array}$ \\
\hline 9 & 4 & 3 & 3 & 0.83 & 83 & $\begin{array}{l}\text { Very } \\
\text { valid }\end{array}$ \\
\hline 10 & 4 & 3 & 3 & 0.83 & 83 & $\begin{array}{l}\text { Very } \\
\text { valid }\end{array}$ \\
\hline 11 & 4 & 3 & 3 & 0.83 & 83 & $\begin{array}{l}\text { Very } \\
\text { valid }\end{array}$ \\
\hline $\begin{array}{l}\text { Averag } \\
\mathrm{e}\end{array}$ & 0.89 & 0.84 & 0.84 & 86 & & $\begin{array}{l}\text { Very } \\
\text { valid }\end{array}$ \\
\hline$\%$ & 89 & 84 & 84 & & & \\
\hline
\end{tabular}

4. Graphics Aspects

\begin{tabular}{|l|l|l|l|l|l|l|}
\hline \multirow{2}{*}{$\begin{array}{l}\text { Indicat } \\
\text { ors }\end{array}$} & \multicolumn{2}{|l|}{ Validator } & \multicolumn{2}{l|}{$\begin{array}{l}\text { Avera } \\
\text { ge }\end{array}$} & & $\begin{array}{l}\text { Catag } \\
\text { ory }\end{array}$ \\
\cline { 2 - 6 } & 1 & 2 & 3 & & & \\
\hline 1 & 4 & 3 & 3 & 0.83 & 83 & $\begin{array}{l}\text { Very } \\
\text { valid }\end{array}$ \\
\hline 2 & 3 & 3 & 4 & 0.83 & 83 & $\begin{array}{l}\text { Very } \\
\text { valid }\end{array}$ \\
\hline 3 & 3 & 3 & 4 & 0.83 & 83 & $\begin{array}{l}\text { Very } \\
\text { valid }\end{array}$ \\
\hline 4 & 4 & 3 & 3 & 0.83 & 83 & $\begin{array}{l}\text { Very } \\
\text { valid }\end{array}$ \\
\hline 5 & 3 & 3 & 4 & 0.83 & 83 & $\begin{array}{l}\text { Very } \\
\text { valid }\end{array}$ \\
\hline 6 & 4 & 3 & 3 & 0.83 & 83 & $\begin{array}{l}\text { Very } \\
\text { valid }\end{array}$ \\
\hline 7 & 4 & 3 & 3 & 0.83 & 83 & $\begin{array}{l}\text { Very } \\
\text { valid }\end{array}$ \\
\hline
\end{tabular}




\begin{tabular}{|l|l|l|l|l|l|l|}
\hline 8 & 4 & 3 & 3 & 0.83 & 83 & $\begin{array}{l}\text { Very } \\
\text { valid }\end{array}$ \\
\hline 9 & 4 & 3 & 3 & 0.83 & 83 & $\begin{array}{l}\text { Very } \\
\text { valid }\end{array}$ \\
\hline 10 & 4 & 3 & 3 & 0.83 & 83 & $\begin{array}{l}\text { Very } \\
\text { valid }\end{array}$ \\
\hline 11 & 4 & 3 & 3 & 0.83 & 83 & $\begin{array}{l}\text { Very } \\
\text { valid }\end{array}$ \\
\hline $\begin{array}{l}\text { Avera } \\
\text { ge }\end{array}$ & 0.93 & 0.75 & 0.82 & 83 & & $\begin{array}{l}\text { Very } \\
\text { valid }\end{array}$ \\
\cline { 1 - 1 } & 93 & 75 & 82 & & & \\
\hline
\end{tabular}

So, through the validation results table, each validator is given the following assessment:

Table 3. Results of Textbook Validation by Validators

\begin{tabular}{|l|l|l|l|}
\hline $\begin{array}{l}\text { Validated } \\
\text { aspects }\end{array}$ & Validator & $\begin{array}{l}\text { Validity } \\
\text { Value (\%) }\end{array}$ & Criteria \\
\hline Content & $\begin{array}{l}\text { Dr. Dwi Hilda Putri, } \\
\text { M.Biomed. }\end{array}$ & $87,50 \%$ & $\begin{array}{l}\text { Very } \\
\text { Valid }\end{array}$ \\
\hline Language & $\begin{array}{l}\text { Dr. Tressyalina, } \\
\text { M.Pd. }\end{array}$ & $79,16 \%$ & Valid \\
\hline Construct & $\begin{array}{l}\text { Dr. Darmansyah, } \\
\text { M.Pd. }\end{array}$ & $84,09 \%$ & $\begin{array}{l}\text { Very } \\
\text { Valid }\end{array}$ \\
\cline { 1 - 1 } Graphics & & $75,00 \%$ & Valid \\
\hline Overall Rating & $81,44 \%$ & $\begin{array}{l}\text { Very } \\
\text { Valid }\end{array}$ \\
\hline
\end{tabular}

Based on Table 3, it can be seen that the content and graphic components already meet the valid category and the language component, the construct has fulfilled the very valid category. Overall average results of research-based bioremediation textbooks are $81.44 \%$ with a very valid category.

The validity of research-based bioremediation textbooks from the content aspect according to the validator is in very valid criteria. This means that developed learning media can be assessed accurately (Trianto, 2010: 55). Accurately the media in the form of textbooks that researchers developed shows that textbooks can be used as a source of information in lectures. The bioremediation material contained in the book has been explained along with research results. The research results are taken from scientific sources in the last 10 years in scientific articles, review journals and research journals from accredited national and international journals. The addition of articles given will make students able to follow the latest issues about bioremediation through research information related to bioremediation. The results of the research are used as learning resources because they can provide concrete examples for students in lectures so that they help students understand ideas, concepts and research theories (Arianti, 2014: 1-8). In addition, research results that have been published in journals will be appropriate to be used as a reference source for developing learning resources with more applicative advantages and meet the present element (Parmin, 2012: 1-8). So, through the research results are expected to facilitate students in understanding the concepts of research that are obtained concretely.

The next is very validity of the textbook because of the relevant pictures and videos that are informed online and offline in order to help understand the bioremediation material. Images and videos are one of the media that can provide a real experience to the target object. The addition of images is very important to be used in an effort to clarify understanding because as a visual communication tool the image also provides wider knowledge (Sanjaya, 2010: 168).Meanwhile, the use of videos that contain images maximally will support a form of learning based on real nature and be able to provide facilities to analyze, provide evidence and draw conclusions from the subject matter of learning provided (Putra \&Sudarti, 2015: 1-14).Therefore, overall the textbooks that are developed are in accordance with the needs of students and needs as textbooks.Subsequent validation results on aspects of language and obtained values in valid criteria. That is, the textbooks that have been developed have been good from the linguistic aspect. Language is one important aspect in the preparation of textbooks (Hamdani, 2012: 22).Language is also considered as a link in the interpretation of meaning (Mudzakir, 2010: 24).The use of language in this textbook is good and right in accordance with Indonesian Spelling (EBI). The description of the material presented in written language has been considered communicative, effective and efficient, but there are still some uses of punctuation, placement of conjunctions and selection of diction that is not quite right. The valid value also comes from the use of logical language and does not contain multiple meanings, so the delivery of material in textbooks can be well received by students.

Evaluation of the validity in the constructed aspect is considered very practical by the validator. This criterion shows that the textbook has been presented with a systematic, clear goal (learning outcome), the indicators to be achieved are in accordance with the order in which the material was presented. Preliminary material contained in the textbook will help students to find out the description of the sub-chapter that will be discussed later and is expected to increase interest in reading or motivation to understand the material in it. Textbooks are also equipped with research results with the aim to broaden students' insights and become one of the ways to provide positive stimulus in lectures. The results of research integrated into textbooks will make learning more applicable and contextual, this is in line with the opinion of Pambudiono (2012: 10) which states that biotechnology requires research-based learning media. and, the addition of information columns is intended to add knowledge that is relevant or that is general to the reader.

The next aspect is graphic, with the values in the criteria valid. These criteria indicate that the layout (layout) and display design is good, referring to the general appearance of the book. The color combination used on the cover looks attractive with a picture showing the appearance of local 
nature and pollution of some pollutants. The color combination in the design of this book also does not interfere with focus when reading because it is only on the top and bottom margins. Research findings are easy to find when they are read because most of them are given a column containing the author, year, and title of the research to be elaborated. The type of writing used semi-formal, namely the type of Brush Script MT, Baskerville old face, Cambria, Colonna MT, Garamond aims to support the appearance of textbooks that are scientific but not too rigid. The size of the letters has been assessed proportionally both on the cover, table of contents, list of images, list of tables, chapter titles, and sub-chapters or for the size of the writing

\section{CONCLUSION}

Based on the results of research and discussion of the results of research-based bioremediation textbooks that have been developed have produced textbooks with highly valid criteria based on content, language, construct, and graphic aspects. The validity results explain that the textbook is appropriate to be used as a reference for bioremediation material in biotechnology lectures. This validity was reviewed from the results of studies of media experts, languages and biologists with a validity level of $81.44 \%$.

\section{ACKNOWLEDGMENT}

The author would like to thank the editors and reviewers of Biosfer: Jurnal Pendidikan Biologi (Biosfer.jpb) who have helped in the publication of this manuscript.

\section{REFERENCES}

Astuti, Y. (2016). "Development of CTL-Based Bioremediation Textbooks for Students".Thesis. Padang: Padang State University Postgraduate Program.

Arianti, Pebri. 2015. "Development of Nuanced Module Research Results in Reproductive Physiology Courses for Biology Students". Unpublished thesis. Padang: UNP.

Hendrianie, N., Sri, R. J., Eko, Y. \& S.,Riski, D. N., "BioremediasiLahanTerkontaminasiMinyakBumi DenganMenggunakanBakteriBacillus cereusPada Slurry Bioreaktor. LaporanPenelitian, (Online) (http://digilib.its.ac.iddiaksestanggal 15 Febuari 2019).

Heerden.E. v., Peter.W., Elizabeth. O., Kay. K., Rohan. P., (2018)."Bioremediation Small Solutions to Big Problems".Online publication. https://www.ufs.ac.za/docs/librariesprovider22/mi crobial-biochemical-and-food-biotechnology- that contains a description of the material that can be read easily and clearly. The size of the image is also proportionally equipped with clear image captions. The existence of the image is intended to reinforce the material and assist in visualizing it (Sanjaya, 2010: 168). in addition, the appearance of the media in this case textbooks, according to Arsyad (2009: 26) can increase and direct the attention of students so as to cause motivation to learn. So, based on the explanation of the four aspects namely aspects of content, language, construct and graphic textbooks are already in the valid categories.

documents/exboc-documents/research-projectsdocuments/bioremediation-2563eng.pdf?sfvrsn=b25af921_0 accessed January 25, 2019).

Mudzakir, A. S. (2010). Quality textbook writing. Library: Bandung.

Parmin, E Peniati. (2012). "Development of Subjects Module for Science Teaching and Learning Strategies Based on Learning Research Results". Indonesian Science Education Journal. Semarang: Semarang State University.

Plomp, T. and Nieveen, N. (2013). "Educational Design Research: An Introduction". Netherland: International SLO Publication.

Putra, P. D. A., \&Sudarti, S. (2015). Real life video evaluation with e-learning system to improve students' critical thinking skills.Journal of Education: Research Learning Innovation, 45 (1).

Riduwan.(2009). Easy Learning Research for Teachers, Employees and Beginner Researchers. Bandung: Alfabeta.

Sanjaya, Vienna. (2010). Standardized Process Education Learning Process. Jakarta: Prenada Media Group.

Soemarwoto, O. (2004). Environmental Impact Analysis. Yogyakarta: GadjahMada University Press.

Tarigan, H. G. and Djago, T. (2009). Study Indonesian Textbooks. Bandung: Space.

Trianto(2010). Designing Innovative-Progressive Learning Models: Concepts, Foundations, and Implementation in Education Unit Level Curriculum (SBC). Jakarta: Kencana. 